\title{
9 Technological Phantoms of the Opéra
}

BENJAMIN WALTON

Commenting on the emerging 'material turn' in opera studies, Jonathan Sterne recently cautioned about the need to define what we mean by a term as 'seductive yet baggy' as materiality. ${ }^{1}$ Yet even if we sidestep the confusion of the competing Marxist, media theoretical, neuroscientific, ontological and ecological materialities that Sterne invokes, to start instead with a more naive quest for opera's historical material traces - its objects and its things - where might the limits of such a search lie ${ }^{2}$ And must the realm of the material for the opera scholar necessarily function, as Sterne suggests, as a way 'to get at the immaterial, the ephemeral, the mortal'? ${ }^{3}$ What, in short, might a material history of opera look like?

Such questions crowd in when writing about the Palais Garnier principal home of the Paris Opéra from 1875 to 1989 - and when feeling at once impressed and oppressed by its material excess, by its overdetermination as a symbol of grand operatic culture, and by its continued existence as a repository for certain kinds of operatic fantasy, indulged as much by the scholars in its library as by the tourists posing on its grand staircase. Perhaps better, then, to approach the question more obliquely: what might a material history of opera seem most likely to leave out? From recent evidence, it would pass over those material traces that seem least enchanted, or least historically innovative, which often amounts to much the same thing, in pursuit of the sort of 'estranging old-time images, eccentric instruments, outré theories [and] fabulous body parts', listed by Carolyn Abbate as beloved of historians of music and science. ${ }^{4}$

\footnotetext{
1 Sterne 2016, 160.

2 On the distinction between objects and things, derived from Heidegger, see Brown 2001. In Brown's terms, objects become things 'when they stop working for us: when the drill breaks, when the car stalls, when the windows get filthy, when their flow within the circuits of production and distribution, consumption and exhibition, has been arrested, however momentarily' (4).

3 Sterne 2016, 160.

4 Abbate 2017, 793; see also the objects listed as focal points of a clutch of materially conscious opera books reviewed by Laura Tunbridge (and also quoted by Sterne): 'one large larynx; two dried testicles; a musical score; a shellac disc; symbols all for the continuing search for something beyond opera's materiality': $(2016,299)$.
} 
Abbate suggests that there is nothing intrinsically wrong with luxuriating in the pleasures of such quirky objets trouvés. ${ }^{5}$ Sterne, though, is not so sure, arguing that the disproportionate attention given to these kinds of artefacts at the expense of others less seductively bewildering - the design of a stage or the architecture of an opera house, for instance - indicates an estrangement of opera from its technological apparatus, with the result that operatic technologies receive attention only when objects of wonder. And quirky objects can quickly lose their shine. Take, for instance, the chronology that opens Karen Henson's recent edited collection of essays on Technology and the Diva - the book for which Sterne's reflections on operatic materiality serve as an afterword. Its authors offer up a trove of heliographs, phonautographs, microphones, wax cylinders, telegraphs, radio broadcasts and moving images. Yet in terms of production history, at least, the resultant catalogue of innovation maps a largely familiar landscape: the invention of limelight in 1803; phantasmagoric grand opéra via the innovative use of gaslight in the 'Ballet des nonnes' in Giacomo Meyerbeer's Robert le diable in 1831, the electrical sunrise of Le Prophète in 1849; a shift away from Paris in the second half of the century with the use of new technology for Parsifal at Bayreuth in 1882; the innovations in scenery and staging proposed in Adolphe Appia's La Musique et la mise en scène of $1899 .{ }^{6}$ Such a progression chimes with other recent work, such as John Tresch's The Romantic Machine, which considers the ways that technology and romanticism, arts and sciences, became thrillingly entwined in Paris in the first half of the nineteenth century, only to unravel faced with 'the mechanistic materialism and rigid disciplinary divisions that took command after midcentury in the Second Empire. ${ }^{7}$

Not that the broad contours of such a narrative necessarily ring false: the failed attempts during the 1860s to develop a revolutionary new system for the stage machinery of the Garnier Opéra, a system that forms the subject of this chapter, foundered in part through the incompatible disciplinary claims to expertise of machinists, engineers, creative personnel and Garnier himself as architect. Meanwhile, if I were to rephrase and refine the question that ended my first paragraph once more, this time to ask what a mechanistically materialist history of opera might look like, the Palais Garnier would seem an obvious place to turn for answers: it was, after all, an edifice explicitly intended to sculpt and gild the cultural prestige and aesthetic riches of opera into monumental form. The failure to innovate at

\footnotetext{
${ }^{5}$ On the seductions of the quirk, see Mathew and Smart 2015.

${ }^{6}$ Clancy, Gutkin and Vágnerová 2016. $\quad{ }^{7}$ Tresch 2012, 19.
} 
the Opéra, moreover, stands in contrast to more successful innovation elsewhere in Europe soon afterwards, as part of a broader story of changing operatic geographies towards the end of the nineteenth century.

As Tresch suggests, though, any elision of technological and aesthetic progress runs into problems in the second half of the century. In terms of the Palais Garnier, for instance, Evan Baker's recent history of operatic production argues that the fires that burnt down the Opéra's previous home, the Salle Le Peletier, in 1873, and the Opéra Comique in 1887, 'presented unique opportunities to initiate new production styles to accompany the newly replaced theaters'. Baker continues, 'the managements proved timid, contenting themselves with reproductions of the earlier stagings' ${ }^{8}$ But the implied equation here of management timidity with continuity of production style is undercut by contemporary discussions of the machinery on which innovative productions depended. An article that appeared in 1884 in the engineering journal Le Génie civil, for instance, listed the 'three principal conditions of theatrical machinery' as follows:

1. To create an illusion for the eyes of the spectator in the hall, through mechanical means as simple and rapid as possible;

2. To offer enough resilience to avoid at all costs any sort of accidental breaking or bending that, seen from the hall, would spoil the progress of the performance and would unfortunately bring down the spectators from the elevated spheres of artistic convention to a petty and sometimes ridiculous reality;

3. To build only scenery that can be taken down quickly and broken down into small pieces, easy to put to one side from one act to the next and to take out of the theatre, when one work is replaced by another. $^{9}$

No Appian calls for revolution here; but instead, innovation figured as a commitment to a spectacular realism that would improve the audience's suspension of disbelief through improvements in construction, speed and

\footnotetext{
8 Baker 2013, 251.

9 '1. Produire l'illusion aux yeux du spectateur placé dans la salle, avec des moyens mécaniques aussi simples et aussi rapides que possible; 2 . Offrir une résistance suffisante pour ne donner lieu, sous aucun prétexte, à un accident quelconque de rupture ou de flexion qui, vu de la salle, nuirait à la marche de la représenation et ramènerait fâcheusement le spectateur des sphères élevées de la convention artistique, à une réalité mesquine et parfois ridicule; 3 . Ne se composer que de parties rapidement démontables et décomposables elles-mêmes en pièces de faible échantillon, faciles à mettre de côté d'un acte à l'autre et à emporter hors du théâtre, lorsqu'un ouvrage cède la place à un autre.' Nansouty 1884, 222.
} 
efficiency. ${ }^{10}$ And this implied a fourth condition, widely discussed elsewhere at the time: the replacement of men by machines. The search for new machinery at the Garnier Opéra was as much shaped by ongoing debates about mechanisation and labour costs across the rapidly expanding Second Empire industrial sector as by any vision of a new approach to operatic production. For some, the 'vast factory' of the new Opéra - as one critic described it at its inauguration in January $1875^{11}$ - could benefit from the sorts of rationalisation introduced in other branches of manufacturing in pursuit of maximally smooth workflows; for others, cultural production could not be equated with other forms of industrial production, while the accumulated expertise of machinists could not be bettered simply by the introduction of new machines.

In what follows, then, my exploration of the saga of the Opéra machinery is shaped by several interconnected ideas, some perhaps more familiar to historians of science than of opera. These include Sterne's definition of technologies as 'repeatable social, cultural and physical processes crystallized into mechanisms', and David Edgerton's advocacy of a use-based technological history (rather than a history fixated on novelty), but they also encompass an attention to technological failure alongside success, and to the potential of a dominant discourse - here the discourse of inexorable progress - to shape solutions to technical questions. ${ }^{12}$ And behind all such issues lies the attempt to reconnect the realm of the technological with the social and the aesthetic in the study of operatic history. Put bluntly: no spectacular operatic productions without machines, and no machines without people to operate them.

My focus, however, falls here not on the massed ranks of the Opéra's machinists, but on the small group tasked with determining which machinery to install; and above all on the young Charles Garnier himself. Garnier first took on the task of designing a new staging system singlehandedly, before participating actively in the Commission (and SubCommissions) to seek a workable solution when his initial ideas were rejected. And it was Garnier, too, who committed the most complete account of the whole episode to print: first in Le Théâtre, published in

10 Appia ruefully stressed the same thing in the second preface of 1918 to his La Musique et la mise en scène, when he wrote that 'the public like the specialists were entirely preoccupied with innovating through an increasing luxuriousness of decorations, or else by an ever-more-perfect realism: and the mise en scène understood in this way condemned the dramaturge to walk on the spot' ('le public comme les spécialistes étaient uniquement préoccupés d'innover par un luxe croissant de décorations, ou bien par un réalisme toujours plus parfait: et la mise en scène ainsi comprise condamnait le dramaturge à piétiner su place'). Quoted in Bablet 1983, 1: 9

11 'cette vaste usine'. Duval 1876, 43. ${ }^{12}$ Sterne 2014, 121; Edgerton 2006. 
1871, and then ten years later in Le Nouvel Opéra. He was responsible, as a result, for laying down an apparently authoritative history of the ultimate failure to install a new system, owing to lack of time and money, and of shaping his role at the centre of things in a way that left enough room for later writers to cast him as a technological visionary, frustrated by pettifogging bureaucracy.

Garnier's close involvement over many years with the question of the machinery, while he simultaneously masterminded the rest of the building's construction, is quite extraordinary; and his desire to include his own version of the deliberations over the machinery as part of his wider description of the project is entirely understandable. But his narrative is partial in ways that only become clear by returning to the quantities of original plans and reports written at each stage of the deliberations. Not that it would be possible to do justice to all the mechanical and interpersonal intricacies these documents reveal within the confines of a single chapter. Indeed, such a cache would arguably require a full-scale immersion in some kind of 'scientifiction' - Bruno Latour's description for his fusion of 'the novel, the bureaucratic dossier, and sociological commentary' developed in Aramis, or the Love of Technology. ${ }^{13}$ Numerous striking parallels could be drawn, in fact, between the ill-fated mission to transform the Opéra machinery and Latour's virtuosic account of the thwarted attempts a century later to introduce a personal rapid transit system to Paris. And in homage to his insistence on the essentially fictional nature of any technological project, as well as in light of Garnier's own later retellings of his quest for the ideal operatic machinery, I divide up what follows into five acts: a kind of dramatic sketch, rendered in disenchanted prose, devoid of any novel special effects, and with Garnier as flawed hero.

\section{Act I}

The official government decree of 29 September 1860 confirming the construction of a new Opéra - to replace the decrepit forty-year-old theatre on the Rue Le Peletier - was notably terse, referring only to the 'public utility' of the project. But there were plenty of people around willing to spell out the stakes at much higher pitch. César Daly, influential editor of the Revue générale de l'architecture et des travaux publics, suggested 'national utility', at the least, given the clear national interest in a project

\footnotetext{
13 Latour 1993.
} 
designed to confirm Paris as the artistic capital of Europe. ${ }^{14}$ And in the months before the decree, Théodore Delamarre, editor of La Patrie, had proposed that 'the new opera house, to answer to the splendour of the capital, must be, in its external proportions, in the grandiose character of its interior layout, a theatre without rival in Europe. ${ }^{15}$ The members of a commission set up by the Prefect of the Seine to review possible locations concurred, proclaiming that the building must be of 'a previously unknown magnificence.. ${ }^{16}$ And so it came to pass: as the concluding lines of a celebratory hymn written for the eventual inauguration on 3 January 1875 would put it: 'France, mother of the arts, fulfil your destiny: / That they should come, your children, to take their place in the festivities! / That before this palace they raise their heads high; / That their brows might be imprinted with a noble pride ... ! / Here is Progress; here is Conquest; here is Grandeur and Immortality! ${ }^{17}$

For all the bombast, this final string of abstract nouns manages to capture something of the near-impossibility underlying the enterprise, stuck between the future imperatives of progress and conquest, and the more ancient claims of grandeur and immortality. How could the Opéra serve both as a showroom for the existing luxury of French and European operatic grandeur, and at the same time look ahead, leading the artform on towards the twentieth century? It is a question that has been posed many times since, perhaps with an eye on the building's ornate classicism, or on the status of the new Opéra as a museum (or mausoleum); a role epitomised by the fact that the night of the inauguration saw a parade of operatic excerpts from the 1820s and 1830s rather than any new composition. ${ }^{18}$ But it was in the realm of stage machinery that some of the

14 Daly 1861, col. 82.

15 'La nouvelle salle de l'Opéra, pour répondre à la splendeur de la capitale, doit être, par ses proportions à l'extérieur, par le caractère grandiose de ses dispositions intérieures, un théâtre sans rival en Europe'. Delamarre 1860.

16 'une magnificence jusqu'à présent inconnue'. Paris, Archives Nationales (hereafter F-Pan), $\mathrm{AJ}^{13}$ 531/III, Charles Chaix d'Est-Ange et al., 'Projet d'une nouvelle salle d'Opéra: Avis de la Commission d'Enquête', 33.

17 'France, mère des arts, accomplis ton destin: / Qu'ils viennent, tes enfants, prendre part au festin! / Que devant ce palais ils lèvent haut la tête; / Que leurs fronts soient empreints d'une noble fierté ... ! / C’est ici le Progrès, c'est ici la Conquète, / C'est ici la Grandeur et l'Immortalité!' Buffenoir 1874, stanza 14.

18 In architectural terms, the Palais Garnier would become a symbol of backward-looking decadence for many twentieth-century modernists, with Corbusier declaring it a 'decor for a funeral' ('un décor d'enterrement'); but such critiques have a much longer history, dating back to the years of the Opéra's construction, and rising in volume in the years after the inauguration. Later defenders of the building's style include Penelope Woolf (1988, 214-35), who argues that it was a successful symbol of Second Empire social progress, and Christopher Curtis Mead (1991), who proposes the building as a demonstration of the 'Renaissance' of French Classicism. At the inauguration O. Le Trioux, writing in the Chronique musicale, declared it to have inaugurated nothing, and that it had celebrated 'neither the past, nor the 
greatest hopes had initially been invested for the creation of something genuinely new; and not before time. As Daly wrote in 1861:

Who would believe it? In an era when the mechanical rules and governs, in a society founded on industry and commerce, both of which depend on the genius of the mechanical; at the heart of the nation most addicted to pleasure, of the town that wants and deserves to have the first Opéra in the world; on the banks of the Seine, no less, where we have learnt to say as often as on the banks of the Thames: Time is money ... who would believe it? The mechanism of scenery has made no progress for two hundred years! In this context, the present Opéra in Paris perfectly resembles the salle des machines, as the old theatre in the Tuileries was called. I don't think I am mistaken in saying that the Opéra of the rue Lepelletier [sic] had installed on its stage all the material from the theatre on the rue Richelieu, demolished [in 1820] following the assassination of the duc de Berry. ${ }^{19}$

The decree announcing the initial competition to decide the architect of the new Opéra, published on 30 December 1860, nevertheless passed over the question of machinery completely, specifying only that the stage should be big enough to hold 400 people, of a depth of 32 metres, and a width of at least 14 metres; and that there should be a store nearby to hold materials from the current repertoire. ${ }^{20}$ But the vastly more detailed programme released in April 1861 - once the 171 entries for the initial competition had been whittled down to just five - clearly spelt out the problems of the current system: all the scenery had to be brought out of storage by hand, leading to progressive deterioration of materials, and involving lengthy entractes while sets were dismantled and others rebuilt. At the same time, many effects had to be foregone altogether because of the time taken to change the décors. ${ }^{21}$

present, nor the future' $(1875,78)$. For a later (and more positive) account of the inauguration, see Patureau 1991, 9-24. Finally, on the stagnation of the repertory more generally, see Charle 2007, esp. 245-50; Huebner 2003, 303-5; and, especially, K. Ellis 2015.

19 'Le croirait-on? à l'époque où la mécanique trône et gouverne, dans une société fondée sur l'industrie et le commerce, dépendant tous deux du génie de la mécanique; au sein de la nation la plus adonnée au plaisir, de la ville qui veut et doit avoir le premier Opéra du monde; sur les bords de la Seine enfin, où l'on a appris à dire aussi bien que sur les bords de la Tamise: Time is money (le temps c'est de l'argent), le croirait-on? Le mécanisme des décors n'a pas fait un progrès depuis deux cents ans! Sous ce rapport, l'Opéra actuel de Paris ressemble parfaitement à la salle des machines, common on appelait l'ancien théâtre construit aux Tuileries. Je crois même ne pas me tromper en disant que l'Opéra de la rue Lepelletier a vu installer sur sa scène tout le matériel du théâtre de la rue Richelieu, démoli à la suite de l'assassinat du duc de Berry.' Daly 1861, col. 96.

20 The decree, signed the Minister of State, Count Walewski, appeared in Le Moniteur universel, and was reprinted in full in Daly 1861, cols. 82-4.

21 The full programme ('Programme pour l'étude du projet d'une nouvelle salle d'Opéra, au point de vue de l'administration et de l'exploitation du théâtre') was dated 18 April 1861, and consisted of 107 numbered sections: see Daly 1861, cols. 108-33. A draft copy, complete with 
The programme offered a solution with a blithe optimism that in hindsight can only seem poignant: 'Nothing ... would be easier, by means of various mechanical procedures simpler than most of those used daily in the most basic industrial workshops, than to operate the most complicated changes of décor in a handful of minutes. ${ }^{22}$ There followed a detailed outline of the new system, which boiled down to two main ideas, with a possible third for a future date. First, the large flats (the châssis) that made up the basic set along with the painted backdrop would slide into place by means of rails attached above the stage, before being turned into position by hand ('since we do not wish to deprive ourselves of the resources of intelligent manual labour, but only to restrict it to operations of detail'). ${ }^{23}$ For this to work, the spaces in the wings would ideally be at least half the width of the stage itself, thereby removing the need for storage beneath the stage. Second, the large free-standing constructions known as praticables, built to simulate mountains or other such structures, could mostly be replaced by 'a simple raising of the ground, if the floor of the theatre were formed of mobile parts lifted by a rack and pinion system'. ${ }^{24}$ This, the programme suggested, would also allow the replacement of the current stage floor, crisscrossed as it was with grooves for sliding in scenery from the sides or from below, with something more solid. ${ }^{25}$ Taken together, the benefits of these measures seemed clear:

economy of material; economy of personnel, twenty people being able then to do a job that today occupies a hundred. What possible progress might not ensue for the art of décor, if simple and prompt manoeuvres allowed the realisation of effects in a few minutes that one wouldn't dare undertake today or that one could only manage through brute strength and expense and with interminable entr'actes! $!^{26}$

emendations can also be found in F-Pan AJ ${ }^{13}$ 451/III. Both Daly 1861 and Mead 1991, 44-98, carry detailed accounts of the competition itself.

22 'Rien ne serait plus facile, ... au moyen de quelques procédés mécaniques plus simples que la plupart de ceux employés journellement dans les moindres ateliers industriels, que d'opérer en quelques minutes les changements de décors les plus compliqués.' 'Programme', section 47; in Daly 1861, col. 116.

23 'car nous n'entendons pas nous priver de la ressource du travail manuel intelligent, mais le réduire aux opérations de détail'; 'Programme', section 48; in Daly 1861, col. 116.

24 'par un simple soulèvement du sol, si le plancher du théâtre était formé de parties mobiles soulevées par des épontilles à crémaillère'; 'Programme', section 53; in Daly 1861, col. 117.

25 The best summary in English of the staging system at this time can be found in the translation of J.-P. Moynet ([1873] 1976). See also Ault 1983.

26 'économie de matériel; économie de personnel, vingt hommes pouvant alors suffire à un travail qui en occupe cent aujourd'hui. Et que de progrès possibles n'entreprendrait pas l'art du décorateur, si des manœuvres simples et promptes permettaient de réaliser en quelques minutes des effets qu'on n'ose entreprendre ou qu'on n'obtient aujourd'hui qu'à force de bras et 
Finally, looking ahead, the programme offered one more idea for the future: some kind of hydraulic system that might enable effects impossible to produce at the present time. The dimensions of the plumber's workshop, the programme stated, should be calculated bearing this possibility in mind.

At such an early stage, questions of space understandably loomed large. An anonymous note from 1860 had observed that 'lack of space ... has for two centuries been an obstacle for any progress in theatrical machinery'. ${ }^{27}$ And when in early 1863 - a year and a half after the second competition ended - the victorious Charles Garnier turned his attention to the question of machinery: in an extended report for the Minister of State, he agreed to create enough space for storage in the wings, and also called for sufficient height, to avoid folding backdrops or curtains stored in the flies. Having spent most of 1862 having the groundwater pumped out at the site, and overseeing the construction of reinforced foundations, Garnier went against the grain in arguing for a deep under-stage area; vital, he insisted, for 'the progress of theatrical machinery'. ${ }^{28}$

As to the two key elements of the programme specifications, at this stage Garnier ruled out replacing the praticables with a movable floor, preferring to find ways of making them lighter and more mobile. He went along, though, with the idea of moving scenery in on rails from above the stage, and proposed closing off the flies from the stage with an iron ceiling, to protect any scenery stored there from fire, and to allow the machinists more space to manoeuvre backcloths and lighting safely. More intriguingly, he also laid out a scheme to operate scene changes with a motor, whether operated by hand, steam, gas or electricity (with a preference for the latter two). Each piece of scenery could then be linked to a sort of keyboard, he suggested: at the touch of a key a machinist could make scenery appear or disappear, thus providing quick and effortless transformations. $^{29}$

Here, then, in 1863, we have Garnier as visionary: master of his brief; eyes fixed steadfastly on the future. And although he opened his 1863 report with an account of the many theatres he had visited across Europe

de dépenses et avec d'interminables entr'actes!' 'Programme', section 55; in Daly 1861, cols. $117-18$.

27 F-Pan, AJ ${ }^{13}$ 453/III: 'Note sur les dimensions que doit avoir la scène de l'Opéra' (1860).

28 '[les] progrès de la machination théâtrale'; $\mathrm{AJ}^{13} 453 / \mathrm{III}$, Garnier, 'Etude sur les Théâtres: Rapport adressé à Son Excellence Monsieur le Comte Walewsky, Ministre d'État', (n.d.), 34. The original copy of the report was dated 25 February 1863.

29 Garnier, 'Etude sur les Théâtres', 38. 
- from his time in Italy as Prix de Rome laureate around 1850 to a recent trip to northern Italy and Germany with Victor Louvet, his second in command - in terms of machinery they had taught him nothing. 'The stages of foreign and French theatres, more or less vast and more or less well appointed,' he wrote, 'provide no interesting information, and the systems of machinery installed there offer no new element that could resolve such an important question': the question, that is, of how to equip the grandest opera house ever built. 'Only serious study of the needs of the stage,' he went on, 'the adoption of benefits as identified, the rejection of defective practices and the judicious use of new discoveries can lead to a successful result. ${ }^{30}$

So the way forward seemed clear. Hidden away in this same report, however, were two details that foreshadowed troubles to come. First, a detail of character: over a decade later, after the completion of the Opéra, Garnier would write that 'the architect who constructs a theatre is always placed between two alternatives: if he does something new, he offends all habits and is called a revolutionary; if he proceeds as before, he betrays all hopes and is called a reactionary'. ${ }^{31}$ The solution, Garnier suggested, was therefore for the architect to do as he pleased; but in questions of machinery, at least, Garnier himself tended to oscillate between the two extremes. No sooner had he written off existing theatrical machinery in his 1863 report, and called for substantial modifications, than he turned back on himself:

We should fear too radical a reform, however, too great an upheaval, which would tend, not only to change the machinery but also, for a doubtful purpose, lead to the complete alteration of the plants, lighting, and all the services connected to the stage. While the current system has many disadvantages that need remedy, it also has some advantages, which are all the better to maintain, as they have been tried and tested in practice and confirmed by experience. ${ }^{32}$

30 'En résumé les scènes des théâtres français et étrangers, plus ou moins vastes et plus ou moins bien disposées, ne donnent aucun enseignement intéressant, et les systèmes des machines qui y sont installées, n'apportent aucun élément nouveau qui puisse servir à résoudre une question aussi importante. C'est donc seulement l'étude sérieuse des besoins de la scène, l'adoption des avantages constatés, le rejet des usages défectueux et l'emploi judicieux des découvertes nouvelles qui doit amener à un résultat satisfaisant.' Garnier, 'Etude sur les Théâtres', 39.

31 'l'architecte qui construit un théâtre est toujours placé entre deux alternatives: s'il fait du nouveau, il froisse toues les manies et on l'appelle révolutionnaire; s'il fait de l'ancien, il trahit toutes les espérances, et on l'appelle réactionnaire'; Garnier 1878-81, 1:199-200.

32 'Cependant il faut craindre une réforme trop radicale, un bouleversement trop complet, qui tendrait, non-seulement à changer la machination, mais, qui entrainerait également, et cela pour un résultat douteux, la modification entière des plantations, de l'éclairage, et de tous les services dépendants de la scène. Si le système actuel a bien des inconvénients auxquels il est 
One could read this as Garnier's attempt to draw a line between technology and aesthetics: change the machines, by all means, but only in order to perfect the recreation of existing staging. But one could also see it evincing a more general caution that could easily lead to the blurring of that same line, with Garnier torn between a desire for innovation and an instinctive appreciation for what had worked well in the past.

The second detail was of a more direct kind: a terse footnote, added some time after the 1863 report's completion, and inserted just at the point where Garnier sketched his vision of the machinist moving scenery at the touch of a button. It read: 'since the period when this report was written, this system has been examined and studied by a special commission and has been rejected as offering too many disadvantages'. ${ }^{33}$ A new solution had to be found.

\section{Act II}

Later in 1863, Garnier took the opportunity to update the new Minister of Fine Arts, Jean-Baptiste Vaillant, on the theatrical machinery, pointing out that if a hydraulic system were considered, as mooted in the 1861 programme, it would have to be integral to the construction of the building, since it would be well-nigh impossible to add later on. ${ }^{34}$ A decision was needed fast, in other words, so as not to hold up construction work, and so Emile Perrin, director of the Opéra, could work out the implications for future operatic productions. The most satisfactory solution, Garnier suggested, would be to set up a commission to study the question. Quite why he thought this is unclear. Perhaps he welcomed the thought of external expertise, not least to assess other proposals for the new machinery that had begun to emerge; perhaps he wanted to devote more time to all the other aspects of the Opéra construction; perhaps he really believed that a

\footnotetext{
nécessaire de remédier, il a aussi quelques avantages, qu'il est d'autant meilleur de conserver, qu'ils ont été éprouvé par la pratique, et consacrés par l'expérience.' Garnier, 'Etude sur les Théâtres', 35. Just before this passage Garnier describes Italian and German machinery as 'in its infancy', and French machinery as better but still beset by problems.

33 'Depuis l'époque à laquelle ce rapport a été écrit, ce système a été examiné et étudié par une Commission spéciale et a été repoussé comme offrant de très-grande inconvénients. [Voir les rapports faits à ce sujet par la commission des machines théâtrales.]' Garnier, 'Etude sur les théâtres', 38.

${ }^{34}$ F-Pan $\mathrm{AJ}^{13}$ 453/III: 'A Son Excellence Monsieur Le Maréchal de France, Ministre de la Maison de l'Empereur et des beaux-arts'. The document includes a date of February 1863 added in blue crayon, but must have been later that year, since Jean-Baptiste Vaillant only took up the post of Minister of Fine Arts in June 1863.
} 
commission would help in reaching a quick consensus. Whatever his reasons, time was certainly pressing: in October 1863 Garnier submitted yet another report to Vaillant saying that work was going slower than hoped, and that to finish in time for the 1867 Exposition (as then intended) he would need more money - Garnier's constant plea throughout the construction process - and immediate knowledge of the system to use for the stage machinery'. ${ }^{35}$

The machinery of government, though, moved even more slowly than the scene changes at the Opera; it was only towards the end of July 1864, nine months later, that Vaillant announced the foundation of a commission whose brief went well beyond the narrow question of hydraulics, to assess all the advantages and disadvantages of the present system, and to bring to the future installation the improvements 'that experience, art and science might judge necessary. ${ }^{36}$ Its twelve members included Garnier and his deputy Louvet; Perrin, as director of the Opéra; and Félix Martin as former general secretary. Five others were practitioners: three of the Opéra's most esteemed scene painters - François Nolau, Édouard Desplechin and Charles-Antoine Cambon, all in their sixties - alongside the Opéra's head machinist for over a decade, Jean-Joseph Sacré, and Monsieur Brabant, the head machinist of the Porte Saint-Martin (and later of the new Opéra). And the final three were expert outsiders: Henri Tresca, engineer and assistant director of the Conservatoire des Arts et Métiers; Etienne de Cardaillac, long-time head of the civilian buildings section of the Department of Public Works (and a member of the 1861 jury); and finally, as president, Victor Regnault, physician, chemist, photographic pioneer and director of the Sèvres porcelain factory.

With the Commission in place, Garnier quickly submitted a summary of his proposed system, prefaced by passages from the 1861 programme. Already, though, his ideas had been toned down: manpower was now declared the best option for moving the scenery, and the master keyboard had disappeared. He also included a caveat that his plans were intended 'merely as a basis for discussion', and claimed that his purpose in formulating a system at all had simply been to indicate the important points to

35 'la connaissance immédiate du système à employer pour la machination de la scène'; F-Pan $\mathrm{AJ}^{13}$ 453/III: 'Nouvel Opéra. Avancement des travaux. Rapport à Son Excellence Monsieur le Maréchal de France, Ministre de la maison de l'Empereur et des Beaux Arts', Paris, 24 October 1863.

36 'que l'expérience, l'art et la science jugeraient nécessaires'. The decree was dated 24 July 1864, and was reprinted in the Revue de l'architecture et des travaux publics 22 (1864), col. 300, where Daly welcomed the formation of the Commission while questioning why it had not been set up before the initiation of the competition to design the Opéra. 
examine'. ${ }^{37}$ The Commission, of which Garnier was almost certainly the youngest member, was now in control.

Three sets of responses to Garnier's plan survive. The first, undated, was from the Sub-Commission (consisting of Perrin, the machinist Sacré, two of the scene painters, Cambon and Despléchin, and Garnier himself) set up to assess all proposals received. It was moderate in tone, but declared the movement of the scenery by rails above the stage as problematic and undesirable. ${ }^{38}$ The second report, dated 25 October 1864, and signed by all three of the Commission's artists, was less temperate, describing the proposal as combining the problems of the current stage with those of systems abandoned fifty years earlier, and ridiculing the idea of the iron ceiling and of manoeuvring the scenery from above. Contrary to popular opinion, stage machinery had indeed progressed over recent decades, they argued; Garnier's project would send them backwards. The only area on which they agreed with Garnier was that a mobile floor was unnecessary; and they also advocated a semi-circular panorama to replace the current backcloth. ${ }^{39}$ The third report, also undated, was from Brabant, machinist of the Porte Saint-Martin; he supported the scene painters in declaring Garnier's system 'completely ... impossible, and a step backwards', although he supported the desire for simplicity and economy of personnel. ${ }^{40}$

Two months later, in December 1864, Garnier collated the SubCommission's response to the four other systems for the new Opéra machinery it had received. ${ }^{41}$ All followed the programme in outlining some kind of mobile floor; one (by Monsieur Barthélemy of Nancy) also proposed a framework for the under-stage machinery made of iron rather than wood; the other three all echoed the scene painters in imagining some sort of panoramic backdrop, two (by the engineers Raignard and Foucault) complete with a central cupola, while the third (Signor Rouchi, from Milan) threw in hydraulic counterweights and new methods to imitate

37 'il ne faut y chercher qu'une base de discussion ... mon but ayant été seulement d'indiquer tous les points importants à examiner'. F-Pan $\mathrm{AJ}^{13}$ 453/III: Garnier, 'Rapport adressé à Messieurs les membres de la commission de décoration et de machination théatrales [sic]' (August 1864), 1.

38 F-Pan AJ ${ }^{13}$ 453/III: 'Projet de Rapport de la Sous-Commission chargée d'examiner, au point de vue de la construction et de la manœuvre, le projet indiqué dans la note de Monsieur Garnier' (n.d.).

39 F-Pan $\mathrm{AJ}^{13}$ 453/III: Cambon, Deplechin [sic], Nolau, 'Nouvelle salle de l'Opéra. Etudes des procédés de décors et de machination. Rapport de la sous-commission de Peinture Scénique' (25 October 1864).

40 F-Pan $\mathrm{AJ}^{13}$ 453/III: 'Rapport de M. Brabant, chef machiniste' (n.d.).

${ }^{41}$ F-Pan AJ ${ }^{13}$ 453/III: Garnier, 'Rapport à Messieurs les Membres de la Commission des machines théatrales' (December 1864). 
wind, thunder and rain. ${ }^{42}$ After much discussion, all were rejected; in a final summary to the Commission in February 1865, Garnier confirmed that the existing system from the Salle Le Peletier was the only one feasible, subject to necessary modifications. ${ }^{43}$

Having gone so rapidly from pioneer of novelty to defender of the status quo, at times Garnier, in summarising the conclusions of the SubCommittee, sounds at this point almost brainwashed. 'Through the elimination of all others', he wrote, 'the present system is the only one acceptable, and the only one that at this point ... can offer all possible resources to the scene painters and to the machinists, enable all effects, and lend itself to all compositions. ${ }^{44}$ Any accusations of falling back on routine were misplaced, he continued, for 'routine is nothing other than experience, and the status quo is only a continuation of good practice. Those who ... not only seek improvements but multiple modifications, but that radically overturn the means currently in use, set themselves up for great disappointment. ${ }^{45}$ As to his own system, unveiled in his initial report of 1863 with such confidence, he now turned against it as 'not my own, but intended to engage with the given programme', and praised the Commission for rejecting it along with the rest. ${ }^{46}$ Anything that impeded the art of the decorators, he concluded, 'cannot be accepted; the decoration is the goal, the machinery the means, and one must never sacrifice the first to the second'. ${ }^{47}$

And that might, perhaps, have been the end of the story; the old guard of Opéra stagehands had won Garnier over, and all that remained was to capitalise on the additional space that the new Opéra stage had to offer, and

${ }^{42}$ Raignard would go on to install a new hydraulic machinery system at the Théâtre du Vaudeville when it moved to the Boulevard de Capucines in 1866, which was sufficiently problematic never to be used. See Gosset 1886, 80; and G. Moynet 1893, 45-6.

${ }^{43}$ F-Pan $\mathrm{AJ}^{13}$ 453/III: Garnier (rapporteur), Perrin, Cambon, Sacré, Despléchins [sic], 'Commission de décoration et de machination théatrales. Minute du rapport adressé à la Commission par la Sous-Commission. Paris. Février 1865.'

44 'Le système actuel ... par le fait de l'élimination de tous les autres, devient le seul acceptable, est aussi jusqu’à présent le seul, qui ... peut offrir toutes les ressources possibles aux décorateurs et aux machinistes, permettre tous les effets, et se préter à toutes les compositions.' 'Rapport adressé à la Commission', 1-2.

45 'la routine n'est autre que l'expérience, et que le statu quo n'est que la continuité du bien. Ceux donc, qui ... cherchent non pas seulement des améliorations, mais bien des modifications, qui renverseraient radicalement les moyens mis en usage, se préparent de grandes déceptions.' 'Rapport adressé à la Commission', 2.

46 'non comme mien, mais comme me paraissant rentre dans un programme donné'; 'Rapport adressé à la Commission', 2.

47 'il ne pourrait être accepté; la décoration est le but, la machination est le moyen, et l'on ne doit jamais sacrifier le premier au second'; 'Rapport adressé à la Commission', 2. 
to address any other matters outstanding. Garnier identified just two: first, whether a motor could be brought in to power the counterweight system, thereby economising on machinists. Second, the matter of that movable floor, despite Garnier's continued reservations. But these were mere wrinkles, Garnier suggested, that could best be handled by the appointment of an expert foreman.

With the basic system in place, Garnier returned to his principal task: overseeing during 1865 the completion of the Operra's exterior shell and the construction of the interior iron superstructure to hold the suspended ceiling, ramps and landings of the auditorium. But in early 1866 he reminded the Minister of Fine Arts that the other details were still to be worked out, and the following month Garnier proposed Sacré, the Opéra's head machinist, as the perfect foreman. ${ }^{48} \mathrm{He}$ also suggested that the Commission could now be wound down. It might be reconvened briefly, he wrote, to finalise the choice of motor, and the exact mechanism for the stage floor, but just for three or four meetings; beyond that its use 'seems doubtful to me, for in any commission there is always one person who talks and rambles the whole time, and prevents serious people from expressing their opinions'. ${ }^{49}$ 'I quite realise', he added, 'that in seeking the dissolution of the Commission, I am taking responsibility for the system, or at least responsibility for its execution, but this doesn't seem to me more weighty that what I already bear for the whole building, and I would find as compensation for this increase in work the enormous advantage of being able to line it up with progress in the construction of the new Opéra. ${ }^{50}$

\section{Act III}

Not only was the Commission not wound down, but in its hands the question of the movable floor transformed rapidly from a detail into a

${ }^{48}$ Pan $\mathrm{AJ}^{13}$ 453/III: Garnier, 'Nouvel Opéra. Rapport à S. E. Monsieur le Maréchal de France, Ministre de la Maison de l'Empereur et des Beaux-Arts. Travaux pendant l'année 1865. Paris, le 19 Janvier 1866', 44; 'Rapport à S.E. Monsieur le Maréchal de France, Ministre de la Maison de l'Empereur et des Beaux Arts. Soumissions diverses: Menuiserie, etc.' (24 February 1866), 10.

49 'me parait douteux, car dans toute commission, il y a presque toujours une personne qui parle et divague tout le temps, et empêche les gens sérieux de dire leur avis'. 'Rapport' (24 February 1866), 10.

50 'Je sais bien qu'en demandant la dissolution de la Commission, j'assume sur moi la responsabilité du système, ou du moins la responsabilité de son exécution, mais elle ne me parait pas plus lourde que celle que j'ai maintenant pour l'édifice, et je trouverais comme compensation dans ce surcroît de travail le grand avantage de pouvoir le diriger suivant le degré d'avancement de la construction du Nouvel Opéra.' 'Rapport' (24 February 1866), 10. 
full-blown technological challenge, and a last-gasp opportunity to prove the Opéra's commitment to the dictates of progress. And at this point a new protagonist enters the drama. In mid-1866, a civil engineer named Auguste Quéruel, who had previously specialised in the construction of steamships, learnt from the Opéra's manager of building works, Monsieur Sabathier, that plans for new machinery had effectively ground to a halt, and that various engineers - including two of the principal construction firms in Paris, Edoux and Farcot - had been officially invited to help, but had declined. ${ }^{51}$ Sabathier therefore passed on to Quéruel the seven official reports so far produced by the Commission, and Quéruel seized the opportunity. By November he had developed a new system, and submitted it to Garnier. ${ }^{52}$ Like Barthélemy, Quéruel proposed an iron framework below the stage, and, like Raignard, Foucault and Rouchi, a panoramic back curtain; he also came up with new methods of lighting the stage, and a sprinkler system to put out fires. More importantly, and in a marked departure from all previous systems, he proposed an extensive hydraulic system below stage, with no fewer than seventy-two presses able to open and close the transverse divisions of the stage (the 'trappes' and 'trappillons'), in order to bring up freestanding scenery (known as 'fermes'), and to move the understage trolleys carrying the flats from either side.

Garnier queried the use of iron, while recognising that it brought advantages in terms of stability; Quéruel followed up in March 1867 with a detailed elaboration of the advantages of hydraulics over pulleys for the entire mechanism of the mobile floor. ${ }^{53}$ A week later, on 29 March, the Opéra's head machinist, Sacré, presented his new proposal to the reconstituted Sub-Commission (now with engineer Henri Tresca as president), who suggested various objections; ${ }^{54}$ in August 1867 a third new proposal

51 A later report revealed that since 1854 Quéruel had been involved with the construction of steamboats using surface condensers and distilled water, before turning to the investigation of theatrical machinery (Quéruel 1869, 737). Quéruel's claim that both Farcot and Edoux had turned down an invitation from the Minister of Fine Arts to involve themselves in designing and installing the machinery came as a response to a question after a talk he gave in 1874; see Quéruel 1874b, 100.

52 The dates of Quéruel's initial reports are taken from the summary given in a later submission: Pan $\mathrm{AJ}^{13}$ 453/III: 'Projet de Machinerie pour le Nouvel Opéra, par A. Queruel, Ingénieur Civil à Paris. Septième mémoire’ (28 October 1868).

53 This was Quéruel's third report, dated 20 March 1867; see Quéruel, 'Septième mémoire', 4.

54 This date is extrapolated from the later revision from Sacré (and his son, who was second-incommand of machinery at the Opéra at the time): Sacré père et fils, 'Mémoire explicatif et rectifié des Plans et d'un Nouveau système de Construction en fer et de Machination de plancher du Nouveau Théâtre Impérial de l'Opéra, adressé à Messieurs les Membres de la Commission de l'Opéra' (29 November 1867), article 20. 
arrived, this time from Brabant, the machinist of the Porte-Saint-Martin (like Sacré, a member of the Commission from the start). ${ }^{55}$

Suddenly, the search for a new system - now centred on the question of the mobile floor - was at full steam again, but with the solution further away than ever. What Garnier had framed in 1865 as the sorting out of a few details had transformed into a new competition to design the stage floor mechanism, complicating the Commission's earlier commitment to the existing system and leaving Garnier still unable to estimate the final cost of the machinery. Back in action, the Sub-Commission duly took a trip to the Porte-Saint-Martin to inspect Brabant's model, also studying the hydraulic apparatus installed at the Lyon railway station. Meanwhile, trying once again to draw things to a conclusion, and with time slipping by, in November 1867 Garnier threw his weight behind a revised version of Sacré's plan, adding a lengthy covering note to stress that the system had been approved by all members of the new Sub-Commission bar one, and that Sacré stood ready to address any objections. Garnier then raised several such objections himself - to do with the rigidity of the frame, the sort of mechanism proposed to move the mobile floor, and how to deal with any malfunctions - in an attempt to pre-empt further discussion, and to guide (or force) the Commission's hand. ${ }^{56}$

Unsurprisingly, given his long experience with the machinery at the Salle Le Peletier, Sacré's proposal was not especially revolutionary, beyond the introduction of the mobile floor and the use of iron for the frame below the stage. Other changes were largely pragmatic and small-scale: the size of the trolleys, for example, would be slightly reduced to make them easier to use and to avoid injury; the height of the basement's first level would be raised so that extras holding lances or horses could gather there without bending double. ${ }^{57}$ But despite Garnier's support of Sacré, Quéruel kept up his own campaign, in October 1867 submitting a further new plan to the Commission with the number of hydraulic presses now reduced to twentyseven, and including examples of how the system would suit key works in the repertoire; in March 1868, he came back to them with a new plan, now without Sabathier, but still with the hydraulics in place. ${ }^{58}$

55 Brabant's project is described in detail in F-Pan $\mathrm{AJ}^{13} 453 / \mathrm{III}$, Henri Tresca, 'Travaux du nouvel opera. Rapport sur la Construction du plancher de la Scène' (August 1869).

${ }^{56}$ F-Pan $\mathrm{AJ}^{13} 453 / \mathrm{III}$, 'Système. Sacré père et fils.' Letter from Garnier to members of the Commission, prefacing Sacré's own 'Mémoire explicatif.

57 Sacré, 'Mémoire explicatif', art. 26.

58 The October 1867 plan is described in Quéruel, 'Septième mémoire'; for the fifth, see F-Pan $\mathrm{AJ}^{13}$ 453/III, 'Mémoire adressé à Messieurs les Membres de la Commission des machines théâtrales pour le Nouvel Opéra par A. Quéruel, Ingénieur Civil’ (15 March 1868). 
Then, in mid-1868, came a breakthrough: a sudden meeting of minds between Garnier and Tresca that 'produced, so to speak, an explosion'. 'After numerous meetings, long discussions and serious studies on the various projects presented', Garnier wrote to the Sub-Commission, 'two members of your Commission had, at a single moment, the same intuition of an astounding system for nearly all the data presented so far, that appeared to be able to resolve completely the problem proposed. ${ }^{59}$ Not that their plans were yet perfect, Garnier added; but questions of detail could be debated later if the Sub-Commission could accept the outlines of their new plan.

Such an implausible 'eureka moment', leading to the sudden crystallisation of a perfect solution, can perhaps best be read as one last attempt by Garnier to jump-start the Commission into a decision: it offered them a compromise between the systems of Sacré and Quéruel, but with no acknowledgment to either, and with a new twist in the form of an iron grid placed under the stage to raise or lower it (in whole or in part) by means of four hydraulic presses at each corner (with pulleys as a back-up) ${ }^{60}$ After much discussion, and some modifications (including a fifth hydraulic press in the centre of the grid) the Sub-Commission was convinced, and commended the plan to the Commission unanimously, but for a single vote of dissent from Sacré, whose own system - and, by implication, whose expertise - was now sidelined. In the Sub-Commission's final report Tresca pulled rank, dismissing Sacré's arguments against their system as 'instinctive rather than technical'. ${ }^{61}$ The laws of progress trumped the cavils of the ageing practitioner.

59 'et fit pour ainsi dire explosion'; 'après de nombreuses réunions, de longues discussions et des études sérieuses sur divers projets présentés, il se produisit ce phénomène que deux membres de votre commission eurent à un moment donné la même intuition d'un système renversant à peu près toutes les données présentées jusqu'à ce jour, et paraissant devoir résoudre complètement le problème proposé'. F-Pan AJ ${ }^{13}$ 453/III: Garnier, 'Note adressée à Messieurs les Membres de la sous-commission de machination scénique', 1.

60 The initial proposal included the possibility of a second grid to act as a counterweight to the first, but this was not supported by the Sub-Commission.

61 'des observations plutôt instinctives que techniques'. F-Pan AJ ${ }^{13}$ 453/III: Tresca, 'Travaux du nouvel Opéra. Rapport sur la Construction du plancher de la Scène’ (1 August 1869), 35. Tresca also outlines Brabant's queries about the system, which he developed in a 'Note adressée à Monsieur Tresca, président de la Sous-Commission des études de machination du Nouvel Opéra'. 


\section{Act IV}

Sacré, however, was not to be silenced easily. In a letter to Regnault, president of the Commission, in August 1868 he tore apart Garnier and Tresca's design, declaring the iron framework a monstrosity and launching a strong attack on using hydraulics in place of pulleys, not least in terms of the safety of the backstage crew. ${ }^{62}$ Moreover, he rejected the implication that progress in staging should be measured according to the criteria of industrial efficiency:

The Theatre is not a factory, and it can never be assimilated to this type of industry. Theory is all very well, it often produces excellent ideas; but the practitioner, the man of practice may not be as backwards as a certain report [i.e. the 1861 programme] addressed to us suggested, [claiming] that for a hundred years and more, the Theatre had remained stationary, and that no progress had been made. In that case, the scene painters and the machinists would be entirely irrelevant. ${ }^{63}$

After a stormy meeting of the Commission in December, at which his intervention was discussed, Sacré wrote again, complaining that Perrin was strongly in favour of the Garnier/Tresca plan only because he saw the chance for 'grand effects', without understanding the mechanics of how to achieve them. Progress drives contemporary life, Sacré wrote, 'but if what we might have accepted as a benefit turns out only to be a mistake, then it would be better to give it up'. ${ }^{64}$ And in these terms, the mobility of the stage floor was altogether unnecessary, he argued, since the spectator would not care how effects were achieved. 'Let us perfect what we know, whatever people might say', he pleaded, one last time, adding that 'the smooth running of a theatre is very simple to understand and to establish'. ${ }^{65}$

Quéruel was not to be silenced either. In October 1868 he submitted his own thoughts on Tresca and Garnier's system, describing it ironically as a 'curious mechanical wonder', and suggesting that the attempt to do

${ }^{62}$ F-Pan AJ ${ }^{13}$ 453/III: Sacré, 'A Monsieur Regnault, président de la Commission de machination et décoration théâtrale' (11 August 1868).

63 'Le Théâtre n'est pas une usine, et l'on ne pourra jamais l'assimiler à ce genre d'industrie. La Théorie est une grande chose, il en sort très souvent d'excellentes idées; mais le praticien, l'homme exercé, qui ne serait pas aussi arrière que dit un certain rapport qui nous a été adressé, que depuis cent ans et plus, le Théâtre était resté stationnaire, qu'aucun progrès n'avait été fait. Alors les décorateurs et les machinistes seraient de bien grandes nullités.' Sacré, 'A Monsieur Regnault', 9.

64 'Mais si ce que nous aurions accepté comme un bienfait, ne devenait qu'une déception, il vaudrait mieux y renoncer.' F-Pan AJ ${ }^{13}$ 453/III: Sacré, letter to Regnault (20 December 1868), 3.

65 'Perfectionnons ce que nous connaissons, malgré tout ce que l'on peut dire. ... Le bon fonctionnement d'un théâtre est très simple à comprendre et à établir.' Sacré, letter to Regnault, 3. 
everything with such a small number of hydraulic presses was as foolhardy as creating 'an omnibus with 500 seats' ${ }^{66} \mathrm{~A}$ few days later, he renewed his bid to persuade the Commission of the superiority of his own plan, inviting them to see a model built at $1 / 20$ scale. He also pointed out that he was the only interested party without a defender on the Commission, and the only one who had had no opportunity to see the other projects. Not that he was complaining, he added; just that he hoped for a serious competition, since 'everyone would gain by it'. ${ }^{67}$

Unfortunately for him, when the Commission visited his model they did so unannounced, and Quéruel lacked the extra help needed to work the machine properly. ${ }^{68}$ But he invited them back in January 1869 , and laid out the benefits of his system one last time. 'No doubt you are amazed by my perseverance in studying this project', he suggested, 'and you might ask yourself how, after lack of success with the Sub-Commission, I still allow myself to keep developing my project for you in the hope of a better outcome. Allow me, I pray, to tell you the reason. I have dug so deep into the question that I can't see how anyone could imagine anything better and more complete than my proposals. ${ }^{39}$ This time, he bolstered his claims with multiple endorsements. One of the Farcot brothers - whose firm had earlier turned down the invitation to develop their own system - was quoted as saying 'for me, the problem is resolved'; Quéruel collected similar puffs from two railway engineers, and from Ferdinand Mathieu, head engineer of the firm of Schneider and Co., who had been responsible for reconstructing the Gare d'Austerlitz a few years before. He ended his pitch at full throttle: 'so you see, among engineers there is but one opinion: the structure is stable and elegant. The mechanism is simple and powerful, the floor rigid and secure; multiple and precise in its movements; at last the problem of the complete mobility of the floor is fully resolved. ${ }^{70}$

66 'un tour de force mécanique curieux'; 'un omnibus à 500 places'. F-Pan AJ ${ }^{13} 453 / \mathrm{III}$ : 'Projet de Machinerie pour le Nouvel Opéra par A. Queruel. Sixième Mémoire’ (22 October 1868), 6.

67 'tout le monde y gagner'. Quéruel, 'Septième Mémoire', 6.

68 The unsuccessful visit is mentioned in F-Pan AJ ${ }^{13}$ 453/III: 'Projet de Machinerie pour le Nouvel Opéra par A. Queruel, Ingénieur Civil, à Paris. Huitième Mémoire’ (20 January 1869), 4.

69 'Sans aucun doute, Messieurs, vous avez dû vous étonner de la persévérance que je mets dans l'étude de ce projet, et vous avez pu vous demander comment, après un insuccès dans la sousCommission, je me permets encore de développer devant vous mon projet et d'en espérer un meilleur sort. Permettez-moi je vous prie de vous en dire la raison. J’ai tellement creusé la question, je crois la posséder si bien, que je ne vois pas ce que l'on pourrait imaginer de meilleur et de plus complet que mes propositions.' Quéruel, 'Huitième Mémoire', 4.

70 'Pour moi, le problème est résolu'; 'Ainsi, Messieurs, vous le voyez, parmi les ingénieurs il n’y a qu'un avis: la charpente est stable et élégante. Le mécanisme est simple et puissant, le plancher 
Later in 1869 Quéruel presented his system to the Société d'encouragement pour l'industrie nationale; in March 1870, he installed - at his own cost - a limited version at the Théâtre de la Gaîté, with hydraulics used to lift the curtain, after Sacré refused him the use of the Opéra stage. Then on 13 July he sent his presentation to Perrin, bemoaning what he called the 'fake competition for machinery at the new Opéra'. ${ }^{71}$ But if he hoped for one last chance, time was not on his side. Less than a week later, the Franco-Prussian War broke out, and all construction of the Opéra came to a complete halt.

\section{Act V}

In the period of enforced rest brought about by the war and then the Commune, Garnier worked on his book Le Théatre: ostensibly a general reflection on theatre as physical space, but in practice all about the unfinished Opéra. He mixed new observations with material filleted from his reports over the previous decade, with chapters on such subjects as lighting, acoustics, heating, interior design and, of course, theatrical machinery. This last opened with some familiar themes: the lack of progress in machine design; the vast numbers of machinists required and time taken for basic manoeuvres; the difficulties of transporting scenery; and the challenges to the successful creation of illusion. Characteristically, however, he also paid tribute to past achievements, and to the flexibility of the system handed down over generations. Then he turned to the work of the Commission, narrating the rejection of the plans by Barthélemy, Raynard, Ronchi and Foucault before rerunning verbatim his 1865 defence of routine as a continuation of good practice. Then came the mission to design the movable stage, and the proposals of Sabatier and Quéruel, Sacré and Brabant, and of course the eureka moment with Tresca.

en place rigide et sûr; dans ses évolutions, multiple et précis; enfin le problème de la mobilité universelle du plancher est pleinement résolu.' Quéruel, 'Huitième Mémoire', 4.

71 'le faux concours de la machinerie du nouvel Opéra'. The charge was made by Quéruel in the cover letter he sent to Perrin along with his description of the Gaité project: F-Pan AJ ${ }^{13} 453 / \mathrm{III}$, letter dated 13 July 1870, followed by 'Mémoire adressé à M. Magne, Architecte Président de la Commission chargée par M. le Préfet de la Seine, d'examiner un moteur hydraulique appliqué à la manœuvre des rideaux du théâtre de la Gaîté, par A. Queruel, Ingénieur Civil.' An undated letter from Quéruel to Perrin held in the same folder states that Garnier will be visiting the Gaité the following day after attending a meeting of the Commission, indicating that Garnier did pay attention to the experiment; a much later account claimed that it had been abandoned due to excessive humidity and water leakage from the hydraulic motor, along with other problems in operation: Vaulabelle and Hémardinquer 1908, 37. 
Garnier's entire narrative in his chapter on machinery is so worthily (so tediously) compendious that it would be hard to imagine that anything has been left out. Yet not only does he omit any mention of his original system, thereby remaining silent about its rejection; he also passes over all subsequent tensions and disagreements, delays and frustrations, adopting the serene tone of a magnanimous chronicler. Each inventor is both praised and critiqued; Quéruel's multiple plans are all declared of interest; Sacré's bitter dissent against Tresca and Garnier's system and even his identity as sole dissenter go unmentioned. Such a fraught period, with the Opéra unfinished and his own position as architect uncertain, was no moment to settle scores. Instead he sought to smooth both the ructions of the past and indicate the way forward. 'One might hope that the new Opéra will inaugurate [the Garnier/Tresca] system,' he concluded, 'but it will perhaps come down to a question of money. The projections in the budget, having used as a point of departure the existing machinery, are manifestly insufficient for the new machinery. ${ }^{72}$ Either way, his work - and that of the Commission itself - was presented as complete and of value, regardless of future events:

whatever the outcome ... [these deliberations] will have served to elucidate important points; if the project is not carried out at the new Opéra, it will perhaps be tried in another theatre; if, on the contrary, as I greatly hope, the attempt will be made at the Opéra, the constructors of scenery will soon be able to study with their own eyes a new and distinctive method, which will open up a path previously unknown. ${ }^{73}$

Coming after so many pages in which all hint of drama has been so studiously excised, this conclusion amounted to a cliffhanger of sorts - if one whose resolution for the later reader remains the best-known part of the whole story. But to hear Garnier's own reaction to the ultimate failure to install a new system at the Opéra, we need to jump ahead - past the Siege of Paris and the Commune, and also past Perrin's replacement as Opéra director by Olivier Halanzier in 1871, past the fire at the Le Peletier in late

72 'on pourrait espérer que le nouvel Opéra inaugurera ce système, mais il faudra peut-être compter avec la question d'argent. Les prévisions du devis ayant eu pour point de départ la machinerie actuelle sont manifestement insuffisantes pour la machinerie nouvelle'; Garnier 1871,305

73 'Dans tous les cas ... ils auront servi à élucider bien des points importants; si le projet n'est pas exécuté au nouvel Opéra, il pourra peut-être être essayé dans un autre théâtre; si au contraire, comme je le désire vivement, l'essai se fait à l'Opéra, les constructeurs scéniques pourront bientôt étudier de visu un moyen nouveau et typique, qui leur ouvrirait une voie inconnue jusqu'alors'; Garnier 1871, 305-6. 
October 1873 and the rushed completion of the new house, without a mobile stage floor, for its inauguration in early 1875 - all the way to Garnier's next publication, Le Nouvel Opéra. ${ }^{74}$ This was on a monumental scale, consisting of two volumes of text in quarto, together with two of steel engravings and chromolithographs, and four that contained 115 albumen silver print photographs, all of elephant folio size; the whole enterprise described by Martin Bressani and Peter Sealy as 'obviously in metonymic relation to the lavishness of the real building', and as 'probably the longest summation for the defense ever pronounced by an architect over a single piece of his work'. ${ }^{75}$ Yet the chapter on theatrical machinery that opens the second text volume, published in 1881, consists simply of a direct copy of the earlier chapter in Le Théâtre, prefaced by a light-hearted defence of selfplagiarism ('Since God recopies, I don't see why I ... can't imitate his example'), ${ }^{76}$ and followed by a resigned summary that leads directly from the earlier conclusion:

Ah well, this new and distinctive method will barely be studied; money for one thing, time for another, have prevented me from putting into action the project I have just spoken of and, as with most commissions, the theatrical commission did little good. ${ }^{77}$

On the upside, Garnier continued, the below-stage area was now prepared so that if a future director ever wanted to install the mobile stage floor they could do so without great expense, since all that was missing was the beams of the grid and the hydraulic motors. For now, though, it was 300,000 francs gone to waste on an unrealised system.

And then, at last, the pent-up frustration of many years breaks through:

Why then this commission, which worked for so long and that seemed duty bound to renew all the scenic machinery? Why all these complaints of the decorators, who pretended that they would no longer be able to produce anything unless the floor could rise and fall at their demand? ${ }^{78}$

${ }^{74}$ Garnier 1878-81, with six atlas folios of plates and photographs (1876-1880).

75 Bressani and Sealy 2011, 199-200.

76 'Puisque le bon Dieu se recopie ainsi, je ne vois pas pourquoi moi ... je n'imiterais pas son exemple'; Garnier 1878-81, 2:2.

77 'Eh bien, l'on n'étudiera guère ce moyen nouveau et typique; l'argent d'un côté, le temps de l'autre, ne m'ont pas permis de mettre à exécution le projet dont je viens de parler et, comme la plupart des commissions, la commission théâtrale n'a pas servi à grand'chose'. Garnier 1878$81,2: 48$.

78 'Pourquoi alors cette commission, qui a travaillé si longtemps et qui semblait devoir renouveler toute la machinerie scénique? Pourquoi enfin toutes ces plaintes des décorateurs, qui 
As in earlier writings, this was followed by a retreat into the values of convention: 'Alas! This is what it is like with many things. One often calls tradition routine, when it means wisdom, and novelty progress when it signifies irrelevance. ${ }^{79}$ Whether the unfinished machinery at the Opéra would be such an irrelevance was not yet clear, he added, since it had never been tried; but 'I greatly fear that this commission had for its goal and its desiderata nothing but some floating sticks thrown into the water by socalled innovators, and that the absolute utility of a mobile floor in a theatre amounts only to a seductive mirage that disappears when approached. ${ }^{80}$ He concludes with the hope that one day he might complete a part of the plan at the Opéra, to avoid future money being spent on a project that might not work.

It is an extraordinary moment in the expensive pages of a book designed to commemorate and disseminate a full account of the successful completion of the grandest opera house in the world. So extraordinary, in fact, that later writers tended to see only the Garnier of Le Théatre, proud of his work, rather than the Garnier of Le Nouvel Opéra, so wary of the imperatives of progress. Alphonse Gosset, for instance, in his Traité de la Construction des Théatres of 1886, cited the Opéra project as a provocation to engineers to innovate, for machinists to awake, and for public opinion to demand the sort of progress visible elsewhere in new buildings. ${ }^{81}$ Similarly, Germain Bapst, in a book on theatre production published in 1893, celebrated the foresight of Garnier's 'ingenious' unrealised project for the movable stage floor; while Edwin Sachs, in his monumental 1896 survey of modern opera houses and theatres, described the failure to innovate at the Opéra 'a great opportunity lost', but added that 'Charles Garnier, I know, still mourns this lost opportunity'. ${ }^{82}$ In his preface to Georges Bourdon's study of English theatres, published in 1903, Sachs went further, noting that in the years since the opening of the Opéra, 'astonishing' innovations in theatrical machinery had appeared in other parts of Europe, but that these had been enabled by the 'strong impetus' created

prétendaient ne pouvoir plus rien composer si le plancher n'avait à leur demande un fux et un reflux alternatifs?' Garnier 1878-81, 2:50.

79 'Hélas! C'est qu'il en est ainsi de bien des choses. On appelle souvent la tradition routine, tandis qu'elle veut dire sagesse, et la nouveauté progrès, tandis qu'elle signifie inconséquence.' Garnier 1878-81, 2:50.

80 'j’ai grand'peur que cette commission n'ait pris pour but de ses desiderata que quelques bâtons flottants jetés dans l'eau par de soi-disant novateurs, et qui l'utilité absolue d'un plancher mobile dans un théâtre ne constitue qu'un séduisant mirage se dissipant lorsqu'on s'en approche'. Garnier 1878-81, 2:50-1.

81 Gosset 1886, 83. ${ }^{82}$ Bapst 1893, 605-6; Sachs 1896-8, 3:24. 
by Garnier's researches during the 1860s at the Opéra; not only did the world's architects and theatre directors remain in his debt, so did all stage engineers. ${ }^{83}$ Bourdon elaborated the point, claiming that if it had been up to Charles Garnier alone, [the Opéra] would surely have become the sumptuous palace of modern machinery'. ${ }^{84}$ Georges Vitoux, in Le Théâtre de l'Avenir (also published in 1903), agreed, casting Garnier with Tresca as heralds of the future. ${ }^{85}$ This image has persisted: George C. Izenour's authoritative Theater Technology, for instance, celebrates Garnier for 'expanding existing French theater technology to the utmost', before listing a variety of 'spatial and technical superlatives' in the design of the Opéra's machinery. ${ }^{86}$

So Garnier got his apotheosis in spite of all his doubts. But other endings to the story are possible. At the Opéra's inauguration, for instance, critics were for the most part too bedazzled by (or disgruntled with) all the finery of the building to pay attention to the machinery; when they did mention it, they welcomed it as just one more element comprising the building's statistical sublimity, wheeling out figures such as the total mass of the counterweights (122,000 kilogrammes of iron and lead), or the total length of cable (223,100 metres of hemp, and 12,700 metres of iron). ${ }^{87}$ Many later writers have remained similarly bedazzled, with much of the secondary literature on the Opéra exploring every aspect of the building but the machinery. ${ }^{88}$ Not that the subject disappeared altogether in the years following the inauguration, of course, nor the same old astonishment at how little theatrical machinery had changed in recent centuries, and how many machinists the Opéra employed; but it would be another forty years before the machinery of the Opéra was overhauled again, and all the wood and hemp finally replaced with metal. ${ }^{89}$

As to Quéruel, last heard of in July 1870, he continued to spread the word about his new system, and to grumble to anyone who would listen

83 Sachs, in Bourdon 1903, vii.

84 'S'il n'avait tenu qu'à Charles Garnier, elle fût devenue à coup sûr le palais somptueux de la machinerie moderne'; Bourdon 1903, 257-8.

85 Vitoux [1903], 166. ${ }^{86}$ Izenour 1996, 22.

87 See, for example, the statistical section that concludes Nuitter 1875, 239-52. Garnier himself includes a chapter rejecting the need to account for the Opéra statistically in his own Nouvel Opéra (1878-81, 2: 237-9)

88 Alongside all the coffee table books on the Opéra (and serious works like Mead's study), it is telling that when the text of Garnier's Le Nouvel Opéra was reprinted in 2001 (available for purchase from the Opéra's bookshop), the second volume was left out, thereby silently omitting the chapter on the machinery (as well as chapters on expenses, heating, lighting, construction, works of art and so on).

89 See F-Pan $\mathrm{AJ}^{13} 1190$. 
about Garnier's behaviour. He published a stinging review of Le Théâtre in the Gazette des architectes in late 1871, in which he mocked Garnier and Tresca's supposedly explosive discovery of the perfect system that turned out to borrow so heavily from his own design; and compared his own reliance on multiple hydraulic motors (criticised by Garnier) with the thousands upon thousands of pulleys, ropes and counterweights in the systems of Sacré and Brabant. ${ }^{90}$ In April 1872 he received a bronze medal for his experiments at the Théatre de la Gaité from the Sociéty for the Encouragement of National Industry, and later that year presented his work to the Society of Civil Engineers. And he returned to the latter Society again one evening in early 1874, explicitly to discuss the machinery at the new Opéra. ${ }^{91}$ He gave an exhaustive account of all the various systems proposed, including his own, grandly concluding that 'public interest cannot remain indifferent to the success of this attempt for reform, proposed on the grandest stage in existence. ${ }^{92}$ Members of the Society seem to have disagreed; for all Quéruel's detail and passion, he received just two questions from the floor before the company moved on to a lecture on developments in the manufacture of phosphorised steel rails at the foundries of Terrenoire; a topic that generated considerably more interest.

Unable to build much support outside the Opéra, Quéruel turned to the pursuit of internal recompense, writing to Garnier on 26 December 1874, after a tour of the completed building, to profess shock at finding a system of machinery so reliant on his plans in a variety of ways, even without hydraulics. ${ }^{93}$ Garnier denied the charge and suggested he write for a second opinion to Tresca or to the Minister of Public Works. ${ }^{94}$ And so he did, in the form of a pamphlet sent to the minister a few months later with a lengthy case for reclamation. First came his argument for the existence of a de facto competition in 1866, then he dug back into earlier reports to argue that Garnier had stolen from Quéruel the idea of building a below-stage frame in iron. He concluded by pointing out that he had devoted enormous time and money to this project, and deserved restitution. ${ }^{95}$

90 Quéruel 1871; the article is dated 7 December 1871. 91 See Quéruel 1869, 1874b.

92 'L'intérêt public ne peut être indifférent à la réussite de cette tentative de réforme que l'on se propose d'inaugurer dans la plus grande scène qui existe'; Quéruel 1874a, 669.

93 Quéruel drew attention to the use of iron for the below-stage structure, and to some more technical details of the construction.

94 This exchange is reproduced in F-Pan AJ ${ }^{13}$ 453/III: Quéruel, 'Machinerie de la scène du Nouvel Opéra. Note à l'appui de la réclamation adressée à Monsieur le Ministre des Travaux Publics'. Garnier's response to Quéruel is partial, however, since Quéruel, like so many others, could not easily decipher Garnier's notoriously messy handwriting.

95 Quéruel, 'Machinerie de la scène'. 
Whether Quéruel's case was successful remains unclear, but it is hard not to feel some sympathy for him: Garnier had borrowed what he needed from his designs, with a focus on pushing through a final plan, but without taking full account of Quéruel's personal investment in the project. And although Quéruel, too, would later receive his own limited apotheosis as another prophet of staging innovation, any signs of his travails and grievances against the Opéra disappeared from the printed record; the contours of his struggle were steamrollered into the flattened grand narrative of inexorable progress. ${ }^{96}$

\section{Epilogue}

At the end of Latour's Aramis, the feasibility of the new light transport system is as uncertain as Garnier's unrealised plans for the Opéra machinery. Would either system have worked or were both destined to remain pipe dreams? ${ }^{97}$ For Aramis, no matter: Latour's engineer protagonist, frustrated with sociology, tells his mentor that following the system's failed implementation, he is returning to the state-of-the-art and to contemplating its future adoption in new configurations and new locations. It would be possible to trace the aftermath of the story of the Opéra's machinery along the same lines; to the foundation of the Asphaleia Society in Vienna, for instance, dedicated to reorganising theatrical design one hydraulic system at a time; and then to the real hydraulics at the Budapest opera house in 1884, at the Halle Stadttheater in 1886, the Berlin Court Theatre and the Vienna Burgtheater in 1888, and the Wiesbaden Opera in $1894 .{ }^{98}$ From there, one could chart the attempts to replace hydraulic power with electricity in moving scenery, as at the Munich's Deutsches Theater in 1896; and so on. That way the historian, like Latour's engineer, gets the vicarious excitement of chasing the next big idea; while the Opéra machinery itself gets pulled within the thrilling world of the once-new, with Garnier's final

96 Gosset 1886, for example, includes a detailed description with plates of Quéruel's hydraulic design (84-7; plate 49); see also G. Moynet 1893, 321-4, along with a description of Quéruel's experiment at the Gaité, together with the reproduction of Henri Tresca's 1871 report on this to the Sociéty for the Encouragement of National Industry.

97 See Latour 1993, 277-8, for the full list of possible conclusions that remained in play at the end of the investigation into the later system, many of which could also be applied to the Opéra machinery ('Aramis has been perfected and will be built soon ... Aramis had almost been perfected; more money and more time were all that would have been needed to complete the experiment ... No piece of Aramis has been perfected. There are no repercussions; it is a false innovation ... It is impossible to judge').

98 On the Asphaleia Society and the development of hydraulics in European theatre machinery see in particular, Pierron 1885; G. Moynet 1893, 214-36; Bourdon 1903, 258-9. 
plan recast as a hydraulic fantasy whose imaginary status only intensifies its appeal: worthy of a place in the operatic curiosity cabinet after all.

Might such a final turn suggest, with Abbate, that there is nothing inherently problematic about the scholarly desire for material enchantment? Certainly some of the select corpus of nineteenth-century publications that go behind the stage of the theatre and opera house present their descriptions of showstopping special effects, novel techniques and grand transformations in conjunction with detailed accounts of the mechanics of operatic machinery; all wrapped up into a kind of catch-all backstage sublimity that somehow survived from the romantic era through the Second Empire and into the Third Republic. The yawning chasms above and below the stage; the towering scenery; the bare-armed teams of machinists, breathless and sweating with the exertions of bringing an opera or ballet to life; even the evocative soundscapes of their work: 'the strange commands [and] bizarre cries that come from the under-stage to lose themselves in the flies'; or the 'grinding of pulleys, lifting the counterweights, and the dull thuds that rock the stage floor ${ }^{99}$ Enough to lure the most spectacle-addicted opera historian out of the stalls and behind the scenes.

Yet while such a move might help to bridge the estrangement between opera and its technologies, in other ways it only risks compounding the original problem, by still treating scholarship as a means to sublimate aesthetic pleasure, and still paying attention to machines and machinists only when remade in mythic form. Better, perhaps, to ground the Opéra machinery within more pragmatic contexts, and the less fanciful the better. The designs for a new cart to transport the Opéra scenery from its off-site store to the stage, for instance, written up in Le Génie civil in 1886; or the vexed issue of set and prop storage more generally. ${ }^{100}$ Or else new developments in fireproofing; or the working conditions of machinists in comparison with other labourers, and the campaign for pension funds to support injured backstage crew and their families. And not forgetting, of course, all the stuff on, above, below, behind and beside the stage - the pulleys, counterweights, flats, trolleys. Objects that were already old-fashioned in the 1860s, and whose familiarity and longevity rendered them invisible as technologies, yet in many cases remain dominant parts of theatrical machinery to this day. The material history of opera, in other words, just found itself a whole lot more material.

99 'Des commandements étranges, des cris bizarres partent du dessous pour se perdre dans les frises'; Vizentini 1868, 10; 'ce sont des grincements de treuils, relevant des contrepoids, et des heurts sourds qui ébranlent le plancher'; G. Moynet 1893, 184.

100 Talansier 1886. 